Journal of Management and Business Aplication

\title{
EMPLOYEE COMMITMENT INCREASE IN VIEWED FROM SOCIALIZATION OF STANDARD SANITATION OPERATIONAL PROCEDURE (SSOP) IN FOOD INDUSTRY COMPANIES (Case Study at PT Yummy Food Utama, Jakarta)
}

\author{
Dwi Rorin Mauludin Insana ${ }^{1}$ \\ Ria Susanti Johan ${ }^{2}$ \\ Indraprasta University PGRI Jakarta \\ Email: dwirorin@gmail.com
}

\begin{abstract}
This study aims to determine whether there is an influence between the socialization of Standard Sanitation Operational Procedures with employee work commitments in food industry companies (Case study at PT. Yummy Food Utama, Jakarta). The method used in this study is a survey method with associative techniques. Data collection was carried out by distributing questionnaires to 30 respondents to find out respondents' perceptions, understanding and satisfaction with the socialization of SSOP, as well as questionnaires for employee commitment in implementing SSOP. Based on the results of calculations and data analysis and discussions that have been carried out, it can be concluded that the socialization of the Standard Sanitation Operational Procedure has a positive and significant relationship with employee work commitments at PT. Yummy Food Utama, Jakarta.
\end{abstract}

Keywords: Standard Sanitation Operational Procedure, Work commitment

\section{INTRODUCTION}

A healthy organization needs a quality management system in order to guarantee the quality of work of the units of an organization as a continuous effort for the survival of a company. In an era that is completely modern with globalization currents like today the existence of a quality management system is a factor that can be the foundation of an organization to be able to survive and compete with international competitors.

The tight competition in the era of globalization causes a company to compete with each other to get as many consumers as possible with a variety of available resources, on the other hand it cannot be denied that consumers are increasingly selective in choosing a product or service of interest. Not only enough to provide the best quality of service in achieving what is called customer satisfaction, but the quality of goods and services offered must also be able to provide quality assurance, so that inevitably to be able to meet the demands of consumers, the implementation of the Standard Sanitation Operational Procedure system must be carried out.

In this case, the Standard Sanitation Operational Procedure (SSOP) becomes a 
compulsory program for an industry to improve the quality of products produced and guarantee the safety system of food products. In the food industry, sanitation encompasses anti-septic activities in the preparation, processing and packaging of food products, cleaning and sanitizing factories and factory environment and worker health. Therefore, all personnel in the food industry must be aware to create clean and hygienic conditions.

According to Winarno and Surono (98: 2004), the SSOP system is included in fulfilling the program's basic requirements for the Hazard Analysis Critical Control Point (HACCP) system. This fulfillment serves to underlie environmental conditions, the implementation of tasks, and other activities in a factory or food industry needed to ensure that a safe production process has been carried out. Sanitation programs must be an important concern in the food industry, both from the managerial level to the operator level. The sanitation program is considered the most effective and has become very important in the food industry to ensure food safety and the successful application of the Hazard Analysis Critical Control Point (HACCP) system. Therefore, all personnel in the food industry must be aware to create clean and hygienic conditions.

In this case, PT. Yummy Food Utama as a food industry company in the field of milk processing always conducts intensive socialization to all employees, especially production employees, people who work and come into direct contact with products. The company instills discipline towards all its employees so that employees have a strong commitment to their awareness of superior product quality.

In order to achieve the vision and mission of PT. Yummy Food Utama demands a number of requirements, including having professional education qualifications and scientific competence, having good communication skills to coordinate with other divisions. This activity is carried out because many work behaviors are influenced by the level of commitment held by employees towards the company where they work, Oktorita Rosyid and Lestari (112: 2001).

At present there are still many companies in Indonesia that have low commitment employees. Low commitment is reflected in the actions of strikes, sabotage, resignation and change of work carried out by employees, Kartono (89: 2003).

A person's commitment to the company's organization is often a very important issue in the world of work. Because of the importance of this, to the extent that some organizations dare to include an element of commitment as one of the conditions for accepting a new employee. This understanding is very important in order to create conducive working conditions so that the company can run efficiently and effectively, Kuntjoro (56: 2002).

The company will be able to grow and be lucky if it can have employees who have high commitment. This is supported by the opinion of Steers and Porter in Rifani (67: 2003) stating that the company will get a positive impact from the existence of employees who have a high commitment to the company because the employee will show a strong desire to continue working optimally and optimally and achieve goals company.

High commitment will show higher performance and productivity. The role of socialization of Standard Sanitation Operational Procedure (SSOP) to the work commitments of employees at PT. Yummy Food Main is very important. Therefore it is necessary to conduct research on the effect of socialization of Standard Sanitation Operational Procedure (SSOP) on employee work commitments at PT. Yummy Food Utama, so workers are able to instill high discipline, loyal attitude and high commitment to the company and understand the importance of producing 
good and right food.

Based on several conceptual theories about the socialization of the Standard Sanitation Operational Procedure and employee work commitments. It is clear that the socialization of Standard Sanitation Operational Procedure has a major influence on the level of employee commitment in a company.

In achieving the goals of the organization or company, the socialization of Standard Sanitation Operational Procedures and employee work commitments is one of the capital that companies need to have in order for the stated objectives to be achieved. Where, the socialization of Standard Sanitation Operational Procedure is a condition that influences arousing, directing and maintaining behavior related to the employee's work commitments.

As is the case with the work environment, the level of employee commitment can be influenced by a number of factors, one of which is the dissemination of Standard Sanitation Operational Procedures that is good, directed and carried out intensively. Therefore, the authors need to conduct research on the effect of socializing Standard Sanitation Operational Procedure with employee work commitments at PT. Yummy Food Utama, Jakarta.

The framework of this study is the variable $\mathrm{x}$ in this case is the socialization of SSOP has a positive relationship and has a significant effect on the variable $\mathrm{Y}$, namely employee work commitment. So the research framework was made as follows:

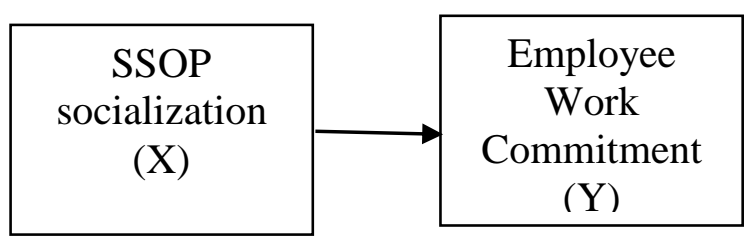

Figure 1. Framework of thinking

The research hypothesis formulated is
H1: Allegedly there is a positive and significant influence from the socialization of Standard Sanitation Operational Procedure on employee work commitments at PT. Yummy Food Utama, Jakarta.

\section{RESEARCH METHODS}

The method used in this study is a survey method, with associative techniques where the variables contained in this study are 2 (two) variables, namely the Independent Variable $(\mathrm{X})$, is the socialization of Standard Sanitation Operational Procedure and the Bound Variable (Y), is a work commitment the employee.

According to Sugiyono (2015) that causal associative quantitative research is research that aims to find out the relationship between two or more variables. Causal relationships are causal relationships. So here there are independent variables (variables that affect) and dipenden (influenced). This research was conducted by giving questionnaires or questionnaires to respondents, where the results obtained are processed into the form of numbers to determine the results of the research that has been done.

In sampling the sample technique used is simple random sampling technique. Where Sugiyono (2015: 83) argues that it is said to be simple (simple) because the taking of members of the population is done randomly without regard to strata that exist in the population.

The basis for determining or sampling according to Roscoe in the book Research Methods For Business (1982: 253) provides advice on sample size for research that is a decent sample size in research is between 30 to 500 respondents. In this study the authors set a sample of 30 people distributed randomly to 100 employees of PT. Yummy Food Utama, Jakarta.

The data used are primary data. Primary data is data obtained directly from research subjects (Azwar, 2013).

Data is collected by giving 
questionnaires or questionnaires to respondents to determine the perception, understanding and satisfaction of respondents on the SSOP socialization that has been done, as well as employee commitment questionnaires in implementing SSOP.

The data obtained is then processed to find the relationship between the two variables. The tabulation and data analysis process will be completed using the SPSS version 20.0 for Windows program.

\section{RESULT ANALYSIS}

\section{Characteristics of Respondents}

The number of respondents as many as 30 people consisted of 3 men and 27 women. With age over 36 years there are 15 people and under 36 there are 15 people. If seen from the level of education most of the respondents were 24 high school graduates, the rest were elementary school (2 people), D3 (1 person) and Bachelor (3 people). Meanwhile, according to the working period of $<5$ years (12 people), the working period of 6-10 years (4 people), the working period of 11-20 years (11 people), the working period of $>20$ years ( 3 people).

\section{Data Description}

Based on the SPSS data output, the data description values shown in Table 1 below are obtained.

Table 1. Descriptive Statistics

\begin{tabular}{lrrr}
\hline & Mean & $\begin{array}{c}\text { Std. } \\
\text { Deviation }\end{array}$ & N \\
\hline $\begin{array}{l}\text { Employee } \\
\text { Commitment }\end{array}$ & 29,00 & 3,096 & 30 \\
$\begin{array}{l}\text { SSOP } \\
\text { Socialization }\end{array}$ & 36,70 & 2,806 & 30 \\
\hline Source: data processed & & &
\end{tabular}

Data in table 1 shows that the average value of employee commitment is 29 with a standard deviation of 3.096, while the average value of SSOP socialization is
36.70 with a standard deviation of 2.806 .

\section{Normality test}

Normality test is carried out to find out whether the data is normally distributed or not. If normally distributed then the data can be continued for further analysis. In the analysis using SPSS normality is shown by the graph as shown in Figure 2. If the data is normally distributed, then the data distribution values will be around a straight line. Figure 1 shows that the data are scattered close around a straight line and are not far apart, so it can be said that the data is normally distributed or normality requirements are met.

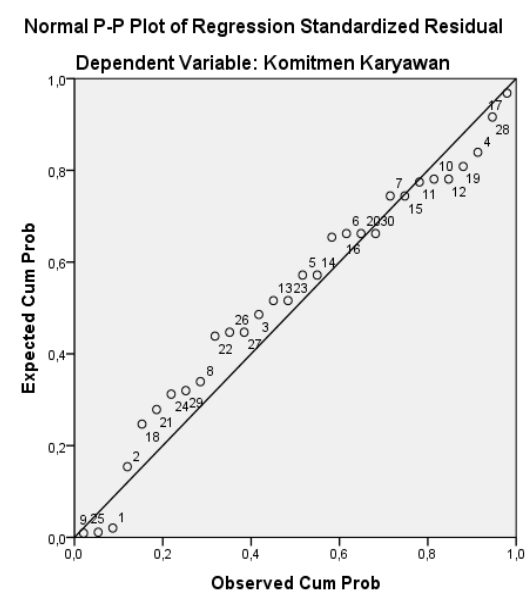

Figure 2. Normality Requirements Test Chart

\section{Regression Equations and Linearity Tests}

Regression equation is used to predict the value of variable $\mathrm{x}$ or or variable $\mathrm{y}$. The data in Table 2 shows the results of the regression equation $\mathrm{Y}=15.979+0.355 \mathrm{X}$, then the constant value (a) of the equation 15.997 means that when the SSOP socialization value is equal to 0 , the employee's work commitment is 15.979 units, and if $\mathrm{b}$ is 0.355 it means that each a $1 \%$ increase in SSOP socialization will increase employee work commitments by 0.355 . 
Table 2. Simple linear regression values

\begin{tabular}{|c|c|c|c|c|c|c|}
\hline \multirow[t]{2}{*}{ Model } & & \multicolumn{2}{|c|}{ Unstandardized Coefficients } & \multirow{2}{*}{$\begin{array}{c}\begin{array}{c}\text { Standardized } \\
\text { Coefficients }\end{array} \\
\text { Beta } \\
\end{array}$} & \multirow[t]{2}{*}{$\mathbf{t}$} & \multirow[t]{2}{*}{ Sig. } \\
\hline & & B & Std. Error & & & \\
\hline \multirow[b]{2}{*}{1} & (Constant) & 15,979 & 7,268 & & 2,199 & ,036 \\
\hline & $\begin{array}{l}\text { Sosialisasi } \\
\text { SSOP }\end{array}$ &, 355 & ,197 & ,322 & 1,797 & 083 \\
\hline a. Depen & dent Variabl & ployee Commitn & & & & \\
\hline
\end{tabular}

Linearity test is performed to test whether the regression model is correct or linear patterned or not. Testing the linearity relationship between the socialization variable SSOP $(\mathrm{X})$ with the employee work commitment variable (Y) shown in Table 3. Based on the calculation results obtained a sig value of 0.083 . This figure is greater than 0.05. This means that between the socialization variable SSOP with employee work commitments have a positive relationship but not linear patterned.

\section{Table 3. ANOVA ${ }^{\mathrm{a}}$}

\begin{tabular}{|c|c|c|c|c|c|c|}
\hline \multicolumn{2}{|c|}{ Model } & $\begin{array}{c}\text { Sum of } \\
\text { Squares }\end{array}$ & df & $\begin{array}{c}\text { Mean } \\
\text { Squar } \\
\text { e }\end{array}$ & $\mathbf{F}$ & Sig. \\
\hline \multirow{3}{*}{1} & Regression & 28,739 & 1 & 28,739 & 3,228 &, 083 \\
\hline & Residual & 249,261 & 28 & 8,902 & & \\
\hline & Total & 278,000 & 29 & & & \\
\hline \multicolumn{7}{|c|}{ a. Dependent Variable: Komitmen Karyawan } \\
\hline
\end{tabular}

\section{Correlation Coefficient Hypothesis Test}

The correlation coefficient is calculated to find out the relationship between the socialization variable SSOP) and the employee commitment variable (Y). The correlation coefficient value is shown by the Pearson Correlation value in table 4 that is equal to 0.322 with a significance level of correlation coefficient of 0.042 or below 0.05 which means it has a significant correlation even though it is low.
Table 4. Correlation Coefficient Values

\begin{tabular}{|c|c|c|c|}
\hline & & $\begin{array}{c}\text { Employee } \\
\text { Commitment }\end{array}$ & $\begin{array}{c}\text { SSOP } \\
\text { socialization } \\
\end{array}$ \\
\hline Pearson & $\begin{array}{l}\text { Employee } \\
\text { Commitment }\end{array}$ & 1,000 &, 322 \\
\hline Correlation & $\begin{array}{l}\text { SSOP } \\
\text { socialization }\end{array}$ &, 322 & 1,000 \\
\hline $\begin{array}{l}\text { Sig. (1- } \\
\text { tailed) }\end{array}$ & $\begin{array}{l}\text { Employee } \\
\text { Commitment } \\
\text { SSOP } \\
\text { socialization }\end{array}$ & , 042 &, 042 \\
\hline $\mathrm{N}$ & $\begin{array}{l}\text { Employee } \\
\text { Commitment } \\
\text { SSOP } \\
\text { socialization }\end{array}$ & 30 & 30 \\
\hline
\end{tabular}

The correlation coefficient value of 0.322 indicates a positive relationship but the level of the relationship is low, this is in accordance with the interpretation of the correlation coefficient proposed by Sugiyono in Table 5.

Table 5. Correlation Coefficient Interpretation

\begin{tabular}{cc}
\hline Internal coefficient & Relationship Level \\
\hline $0.00-0.19$ & Very low \\
$0.20-0.39$ & Low \\
$0.40-0.59$ & Is \\
$0.60-0.79$ & High \\
$0.80-1.00$ & Very high \\
\hline Source: Sugiyono (2015)
\end{tabular}

\section{Coefficient of Determination}

The coefficient of determination is calculated to find out how much the variable $x$ contributes affects the variable $y$. In this case the value of the coefficient of determination is shown by the value of $\mathrm{R}$ Square in table 6 . The figure of $\mathrm{R}$ Square or the coefficient of determination (KD) in Table 6 is equal to 0.103 or equal to $10.3 \%$. This means that the socialization variable SSOP $(\mathrm{X})$ has an effect of $10.3 \%$ 
on the employee's work commission variable $(\mathrm{Y})$. In other words, employee commitment can be explained by $10.3 \%$ by the socialization variable SSOP, while the rest, which is $89.7 \%$ must be explained by other causative factors originating from outside this regression model.

Table 6. Determination Coefficient Values

\begin{tabular}{lcccr}
\hline Model & R & $\begin{array}{c}\text { R } \\
\text { Square }\end{array}$ & $\begin{array}{c}\text { Adjusted R } \\
\text { Square }\end{array}$ & $\begin{array}{c}\text { Std. Error } \\
\text { of the } \\
\text { Estimate }\end{array}$ \\
\hline $1 \quad, 322 \mathrm{a}$ &, 103 &, 071 & 2,984 \\
a. Predictors: (Constant), SSOP Socialization & \\
b. Dependent Variable: Employee Commitment
\end{tabular}

Source: data processed

\section{Hypothesis test (t test)}

Hypothesis test or t test is done to test the truth of the hypothesis and prove whether the research hypothesis is accepted or not.

Furthermore, to prove whether the Zero Hypothesis (Ho) or the Work Hypothesis (Ha) is accepted, the next step is to compare tcount with ttable. The hypothesis test criteria are as follows:

1. If the value of $t_{\text {count it }}>t$ table, the null hypothesis (Ho) is rejected and the alternative hypothesis (Ha) is accepted.

2. If value tcount <ttable, then the null hypothesis (Ho) is accepted and the alternative hypothesis $(\mathrm{Ha})$ is rejected.

To get the tcount, the writer uses the formula:

$$
t=\frac{r \sqrt{n-2}}{\sqrt{1-r^{2}}}
$$

The value of $r$ is the value of the correlation coefficient that is equal to 0.322 . Then the value of $r$ is entered into the formula, then the t-value of 1.786 will be obtained. Meanwhile, to find the table, the author uses a level of trust or significance level of $5 \%$, with degrees of freedom $(\mathrm{dk})=\mathrm{n}-2=30-2=28$, then the table is obtained as follows: t0.05 (30) =
1.701 So, ttable $=1,701$.

Thus, because tcount> ttable is "1.786> 1.701, it means that the null hypothesis (Ho) is rejected and the alternative hypothesis (Ha) is accepted.

From the results of this calculation, it means that the Alternative Hypothesis ( $\mathrm{Ha})$ is accepted, that there is a positive and significant relationship between the socialization of the Standard Sanitation Operational Procedure with the work commitment of employees at PT. Yummy Food Utama, Jakarta.

\section{INTERPRETATION}

Based on the research results obtained that the regression equation that shows a positive value but not linear patterned it turns out this is also shown also by the value of the correlation coefficient and determination are low .. Then from the results of the hypothesis test shows a significantly low value when seen from its tcount which is almost approaching table. This means the SSOP socialization variable in the case at PT. Yummy Food has a low correlation and only affects $10 \%$ of employee work commitment variables so that it has little effect on increasing employee work commitment or it can be said that employee work commitment in implementing SSOP is not determined by SSOP socialization but rather is determined by variables other.

Then Firmansyah, et al (2017) mentioned that the main problem in increasing commitment to implementing occupational health and safety is the lack of quality human resources. If seen from the characteristics of respondents in this study nearly $80 \%$ of high school education background, of which only $10 \%$ of undergraduate graduates. This can affect the character and work commitment related to the implementation of SSOP.

Seeing these conditions, the implementation of socialization can still be carried out but the most important thing to 
increase employee work commitment is to improve the quality of human resources in this case so that employees are able to understand SSOP well and programmed, continuous and documented monitoring of the company towards the implementation of SSOP by each employee.

\section{CONCLUSION}

Based on the results of calculations and data analysis and discussions that have been carried out, it can be concluded that the implementation of the Standardization Sanitation Operational Procedure socialization has a positive relationship with low correlation and little effect on employee work commitments at PT. Yummy Food Utama, Jakarta.

\section{IMPLICATIONS}

Based on the research results obtained, several implications that can be conveyed to the company management need to continue to maintain and improve the intensive socialization of the Standard Sanitation Operational Procedure to employees, then it is necessary to monitor the implementation of SSOP activities in a morphographic and documented manner. and improve the quality of its human resources, in this case employees.

Whereas employees should continue to strive to increase commitment to work. Whatever commitment and motivation is the basis for employees to work continuously must be explored, most importantly can have a positive influence to improve the performance of these employees.

\section{REFERENCES}

Adams and Motarjemi. 2004. Fundamentals of Food Safety for Health Care Workers. Jakarta (ID). EGC.

Afni, Alia Nur. 2016. General Organizational Theory Decision Making. Paper. Gunadarma University.
Alex, S, Nitisemito. 2001. Personnel Management. Jakarta: Ghalia Indonesia.

Anthony, Robert N. And Vijay Govindarajan. 2002. Management Control Systems. Translation by Kurniawan Tjakrawala. Jakarta: Salemba Empat.

Arikunto, Suharsimi.2013. Research Procedure, A Practice Approach. 15th print. Jakarta: PT. Rineka Cipta.

Azwar, Saifuddin. (2013). Research methods. Yogyakarta: Student Library. Efendi, Marihot Tua. 2005. Human Resource Management, 3rd Printing. Jakarta: PT. Grasindo.

Firmansyah, Faith., Et al. (2017). Strategies to Increase Commitment to the Implementation of Occupational Healthand Safety at X Hospital in 2017. Journal of Health, Vol.10, No.2 November 2017.

Flippo, Edwin B. 2002. Personnel Management, Fifth Edition. Singapore: Megrawill.

Food and Drag Administration. (FAD). 2018. Sanitation Standard Operating Procedure.

Ghozali, Imam. 2016. Multivariate Analysis Application with SPSS Program. Semarang: Diponegoro University Publisher Agency.

Hasibuan. 2004. Human Resource Management. Jakarta: PT. Holy mountain.

Handoko, T.Hani. 2008. Personnel Management \& Human Resources, 2nd edition. Yogyakarta: PBFE of Gajah Mada University.

Irfana, Nadira. 2018. Evaluation of the Application of GMP and Preparation of SSOP and HACCP Plan for Products in IRTP Bakery XYZ. Thesis. IPB. Bogor.

Lekatompessy, Jantje Eduard. 2012. The Role of Management Control Systems in Improving Company Performance. Dissertation. Diponegoro University Semarang. 
Mangkunegara, Anwar Prabu.2011. Corporate Human Resource Management. Bandung: PT. Teen Rosdakarya.

Nugroho, Cahyo Adi, 2015. The Effect of Leadership Style and Work Discipline on Employee Performance of DIY Tourism Office. Thesis. Yogyakarta State University.

Pratiwi, Riska. 2012. The Effect of Organizational Culture on Employee Performance at the Office of State Assets Services and Makassar Auction. Thesis. Hasanuddin University.

Reggio, Ronald E. 2009. Introduction To Industrial / Organizational Psychology, Fifth Edition. New Jersey: Pearson Education Inc.

Robbin, Stephen P. 2008. Organizational Behavior, Issue 12, Jakarta: PT. Gramedia Group Index.

Robbins, Stephen P. and Timothy A. Judge. 2015. Organizational Behavior. Jakarta: Salemba Empat.
Sefudin, Akhmad, et al. 2012. Human Resource Management. Jakarta: Indrasprasta University PGRI.

Siagian, SF 2009. Human Resources Management. Jakarta: PT. Holy mountain.

Sopiah, 2008, Organizational Behavior. Yogyakarta: Andi Offset.

Sugiyono, 2015, Quantitative, Qualitative, and R\&D Research Methods. Bandung: AFABETA

Sugiyono 2010. Business Research Methods. 15th edition, Bandung: Alfabeta.

Thaheer, H. 2005. HACCP Management System. Jakarta (ID); Earth Literacy.

Uyanto, SS 2009. Guidelines for Data Analysis with SPSS, Third edition. Yogyakarta: Graha Science.

Winarno, FG, and Surono. 2004. GMP Good Method of Food Processing, Bogor: M-Brio 